\title{
IS CHRIST PROCLAIMED TO CHRISTIANS? THE IMPACT OF SCOTTISH EVANGELICALISM ON HUNGARIAN THEOLOGY, PIETY, AND PRAXIS (1841-1945)
}

\author{
ÁBRAHÁM KOVÁCs* (Guest Author)
}

János Selye University, Slovakia

\begin{abstract}
This paper offers a concise overview of the impact made by Scottish evangelicalism of the Free Church of Scotland on the theology, piety and practice of Hungarian Reformed faith within the Austro-Hungarian Empire. They planted a kind of piety that was foreign, at least in its language and expressions, to most of the Hungarian Reformed people until the arrival of Scottish missionaries in 1841. Their conduct of practical Christianity, praxis pietatis materialised itself in Christian evangelism and social action. In this paper the focus is on the period between 1865 and 1914. To demonstrate the nature and form of this impact, first the paper outlines some key features of Scottish evangelicalism. Then, it investigates the theological and ecclesiastical impact of Scottish evangelicalism made through the establishment of voluntary societies and examines influence on the piety and praxis of Reformed faith in Hungary.
\end{abstract}

KEYWORDS: Eschatology, biblicism, voluntarianism, conversionism, evangelicalism, Hungary

\section{The Features of Scottish Evangelicalism: Eschatology, Election, Providence, and the Missionary Fervour}

It is a well-known fact that extensive Scottish missionary endeavour was initiated amongst the people of Africa, Asia, the Americas or the Middle East but much less is known that they did the same also in Europe. This aspect is much neglected in mission history for number of reason that is not part of our paper. The Church of Scotland, later Free 'Kirk' initiated a curious but biblical mission to the Jews, the ancient people of God in Europe. Gavin White superbly illustrated why the Jewish mission differed from any of the other mission initiatives from the Scots in suggesting that it was an initiative of a national church not of societies (White 1977: 114-116). Nineteenth century Victorian evangelicalism, in which Scottish Reformed theologians played a vital role, primarily sought to bring the gospel to people 'living in darkness' outside Christian Europe (Randall 2001). Yet the Scots arrived to

* ABRAHAM KOVACS (PhD 2003, University of Edinburgh) is Professor of Historical and Systematic Theology at János Selye University, located in the city of Komárno, Slovakia.Email: abraham.kovacs@ptsem.edu. 
the Christian country of Hungary which had Roman Catholics and Protestants as well. It remains an intriguing question why the Scottish Reformed people thought to preach Christ to Hungarian Christians. The answer lies in the fact that it was not their initial aim. When the first missionaries arrived to Budapest, Hungary in 1841, their primary concern was to convert the Jews. Promotion of an evangelical revival among the Protestants and nurturing of evangelical congregations were secondary to their primer aim. Before introducing the Hungarian situation, the paper describes some of major features of Scottish Evangelicalism that profoundly impacted Hungarian Reformed piety.

The Free Kirk Scottish missionaries were all part of British evangelicalism and many scholars argue that their Victorian evangelicalism was an heir of Puritanism. Scottish evangelicalism, with its emphasis on moral conduct, personal devotion, prayer, strict observance of the Sabbath and stress on abstinence from practicing 'sports' and attending balls, left an indelible imprint not only in Scotland but all over the world where they sent missionaries (Bebbington 1996: 23-36). Revivalism within 'Protestant religion' in Britain, taking shape in the form of renewal movements such as various forms of methods (do's and don'ts) and voluntary societies, paved the way for a broad evangelical movement. By the 1800s, Scottish evangelicals were strengthened in their belief that they were called to manifest God's grace, share the good news with people and combat Roman Catholicism and infidelity in the newly colonised lands. This mission was particularly evident during the reign of Queen Victoria (1837-1901). Thus, 'constrained by a fervent love for Jesus' to share the gospel became a strong characteristic mission of British Evangelicalism; the result of a great missionary input from Scottish reformed theology of the Free Kirk (Chalmers 1846). Scots participated in the establishment of mission, Bible and Tract societies as well as Christian voluntary organisations in great numbers (Walls 1993: 567594). They also perceived themselves as a chosen nation to fulfil God's mandate to evangelise the world, convert the pagans and bring the Jews to Christ so as to hasten the return of Jesus Christ the Lord. In this carefully devised plan based on special interpretation of the difficult eschatological passages of the Bible, the conversion of the Jews was a prerequisite of Jesus' Second Coming (Scult 1978: 32-34). Behind this extraordinary phenomenon of intensified mission activity laid a conviction and deeply rooted belief in the partaking of God's salvific plan, where Scottish Christians were assigned a special role. Indeed, eschatology was a prevailing feature of evangelical theological thinking. The vast and popular eschatological literature produced by pre- and postmillennial Scottish theologians, ministers and laymen about the 'exact plans' of God's mission, Jesus's return and the arrival of the golden age, the millennium is chiefly responsible for carrying out 
a really devout mission (Keith 1833). [Keith's books were best-sellers during his time since many of his massive and lengthy books were published more than forty times.]

Although the Scottish reformed people rarely encountered any Jews, since few of them resided in Scotland, the evangelical interpretation of eschatology rediscovered their special role in God's salvific plan (Kovács 2006). Thus, in 1838, Scottish Reformed evangelicalism initiated a mission to 'save' the Jews across Europe, including Hungary (White 1977: 111-124) Buda and Pest, the to-be-capital town of Hungary, became a thriving centre for European Jews migrating from the neighbouring lands. The Church of Scotland decided to establish a mission station to reach out to the Jews in Hungary. However, they soon realised that their aims could not be achieved without the support of Hungarian Reformed Church. John Duncan, the later famous New College professor, who was the first missionary in Pest, realised that if they wish to succeed in converting the Jews to Christ, they need to transplant evangelical faith into the very Hungarian Reformed soul. Only together could they reach out to the Jews. To the Scots, their coreligionist Hungarians were nominal Christians, who also needed to be evangelised and converted to Christ; just as it was a necessity to share the gospel with the Jews (White 1977: 45). The Scottish missionaries were aware of the fact that, if they wanted to preach the gospel successfully among the Jews, they needed to convert at least some Hungarian congregations to evangelical Christianity; which would allow them to exhibit the same kind of godly life they wished to see in the daily life and practice of all Christians. The Scots prayed for a revival to be spread among Hungarian Reformed congregations. To achieve this end, Scots missionaries established a strategic plan step-by-step to influence Hungarian Reformed piety and explain to them how and why they should act and behave differently as Christians, which was strange, unusual and alien to Hungarians (Kovács 2001). As a result, they failed to make an impact for some decades.

After some initial success in the 1840s, the Scots were expelled from Hungary by the Habsburg Monarchy as Protestant spies in 1852. This was the time of Neo-absolutism after the loss of Second War of Liberation fought by Hungarians between 1848 and 1849. While the Scots silently managed to resettle in Hungary from 1857 onwards, they failed to adapt to Hungarian culture and take the multi-religious and cultural dynamic of the society into account, in addition to being ignorant about the nature of Hungarian Calvinism (Kovács 2004). The Scots were not only unable to convert large number of Jews but were also unsuccessful in introducing evangelicalism in Hungary for decades. Their initial lack of success resulted from an unfavourable political situation as well as their inability to connect to the local culture. However, when the Scottish missionaries resettled in 
Budapest from 1857, they realised that the best means to influence Hungarian Calvinism was to establish a bursary programme for students to study at New College, Edinburgh. It was realised only in 1865 but it did prove to be the key means that enabled the Scottish evangelicals to transplant their kind of piety and praxis into Hungarian Calvinism.

\section{The Scottish Evangelical View on Hungarian Calvinism}

Scottish missionaries were very slow to realise what accounted for the peculiarities of Hungarian Reformed piety, rational Christian belief and reluctance to embrace wholeheartedly their way of Christian life. The Scottish evangelicals, like many missionaries today, travelled to a country to share the good news, but often had little knowledge of, or sympathy with, the indigenous culture or previous kinds of Christianity to be found there. In Hungary, the Scots spent years and failed to make any headway before actually reaching their goal to revive the Reformed congregations of Hungary in a mission to convert the Jews. Duncan had a low view of the piety of Hungarian Calvinist. He wrote to the Church of Scotland: 'the mass of Protestant clergy, if not neologians, are careless men, dumb dogs that cannot bar' (Duncan 1842: 44). He realised that the Scots needed to proclaim Christ to the Reformed 'pagans' which he articulated in the following vein: 'Certain I am, that if we are by the blessing of God to succeed in our aim in this place, it must be by pursuing it, as the main object indeed, but by no means as the sole [Duncan's italics] object of our exertions. While matters are in so lamentable a state as they are here, as to religion and morals, even among professed Protestants, the most serious of all impediments remains in the way of Israel's conversion. I am therefore very decidedly of the opinion that whoever shall be stationed here must make it his study, as far as the Lord may vouchsafe opportunities, to labour for the revival of true Religion (both as regards sound doctrine and godly living) in the Protestant Churches of the land [italics added], which would then become, instead of a stumbling block, as now, the best instruments for carrying on the blessed work of gathering in the lost sheep of the house of Israel [italics added] to the Shepherd and Bishop of souls' (Duncan 1842: 45).

Nonetheless, the Scottish missionaries were isolated within the Reformed Church of Hungary due to their inability to learn Hungarian, the unfavourable political climate that disadvantaged Protestants from 1849 onwards almost till the mid-1860s and the emerging liberal thoughts in Budapest. It had taken three decades after their arrival for the Scots to make a tangible, significant theological impact on Hungarian Reformed faith. Debrecen Reformed College with its university became key place where British evangelicalism gradually made its effect and then it spread to other colleges of Reformed faith. 
The Scottish evangelical influence was exerted in two areas in Hungary: theology, and the establishment of home mission societies. Theological influence felt its impact at scholarly level as well as among the ordinary church folk that was content with what I call theology of the people. The second, the introduction of Christian societies, previously completely unknown to Hungary served to provide a reaffirmation of the traditional belief that was expressed both in a neat, carefully articulated writings as well as in popular literature.

One of the most decisive Scottish influences on Reformed faith in Hungary was the establishment of a scholarship programme at New College, Edinburgh in 1865 (Gaál 2004: 177-186). This programme quickly bore its fruit when one of programme's graduating students, Ferenc Balogh, became professor of Church History at Debrecen Reformed College. Importantly, he integrated Scottish evangelical theology into his teaching and publications. Together with Imre Révész senior, the powerful minister of Great Church in Debrecen, he fought a battle against the extreme claims of liberal theology that imported ideas from German, Swiss, Dutch liberal theological schools (Kovács 2010). Scottish evangelical theology of the Free Kirk, which split off in 1843 from the Church of Scotland, lent support for and gave an impetus to the New Orthodoxy Movement from the mid1860s. Debrecen Confession of Faith written and signed by professors of theology in 1875. The Confession of Faith was a protest against the liberal Protestant Union led by Mór Ballagi, a professor from Budapest. In Debrecen, Balogh and his colleagues emphasised the same fundamental doctrines spelled out in the Apostle Creed and evangelical Confession of Faith in 1846. This confessional statement marked a decisive turning point in the spiritual and theological history of the Reformed Church of Hungary and had a number of consequences. Firstly, it defended the orthodox faith and forced the so far dominant liberal theological forces to retreat. As a result, the Scottish evangelical theological impact within the Hungarian Reformed church began to advance faster. It did not mean that the Debrecen Confession of Faith cited words from the works of Scottish Free Kirk theologians but the text of the declaration is, as mentioned above, was in line with the traditional tenets of Christianity that was dear not only the Free Kirk church people but also to the New orthodoxy movement. Secondly, Scottish Free Kirk evangelicals began to make an impact only when they realised the need to establish a scholarship programme and their missionaries in Budapest need to adapt to Hungarian culture and learn the language (Kovács 2006). To achieve their aims, the Scots also employed some of the bursars who returned from Edinburgh at the mission school established to educate Jews with a view to convert them. On the top of that through opening to all the five centres of Calvinist learning in Hungary: Debrecen, Budapest, 
Sárospatak, Pápa, and Kolozsvár, the Scots managed to successfully establish vital links with those key people through whom evangelicalism could advance.

\section{Christology Defended: a Shared Theological Conviction}

The main centre of liberal theology was at the Theological School in Budapest whereas Debrecen College became the forerunner of a neo-orthodox stance. Ferenc Balogh's role was crucial for New Orthodox movement. The Scottish impact is easily discernible from his letter: 'Last October there was founded an anti-evangelical [italics added] society under the name Hungarian Protestant Union... We reject the Unitarian principles of that Union, and adopt the true basis of the gospel, the principles of the Evangelical Alliance. There is now a great distance between their standpoint and ours. They call themselves modern, liberal; and they style us orthodox, and obscured. We are happy to be orthodox, because we do not shame the glorious name of Jesus Christ. There shall be a war, or rather a rupture, among us' (Moody-Stuart 1872: 95).

The conflict evoked a confessional response from Debrecen which was in accordance with the Apostle's Creed and shared the same doctrines of evangelicals spelled out as a Statement of Faith in 1846. The New Orthodoxy of Debrecen, which owed its name and emergence to the liberal theology provoking a response from confession orientated theologians and ministers 'awakening from their slumber' insisted on the divine inspiration, authority and sufficiency of the Scriptures. They maintained the right to private investigation and interpretation of the Bible but for them it was obvious that this exercise had to be in line with the confession of faith expressed in the symbolic writings of the church. The confession explicitly underlined the unity of the Godhead, and the Trinity of the persons therein and did not allow for Christological concessions made by liberal theologians whom they charged with repeating almost all the unorthodox teachings of the patristic period. The Confession of Debrecen highlighted that the utter corruption of human nature due to the Fall meant that every human being is born in sin, therefore is in need of salvation. The saving grace of God may come only though Christ's atonement and the work of the Holy Spirit enlightens us to recognise our fallen state. Liberal theology spoke only about a historical person named Jesus, who was either like God, or a god but less than God the Father, or was adopted and then elevated to the level of Godhead. It was never able to say that Jesus Christ is, was and will be God forever. Hungarian Reformed liberal theology rejected the basic tenets of Christian faith. Countless apologetics of Debrecen New Orthodoxy were quick to point out that is why liberal theology wished to discard the sacrament of the Lord Supper from worship as they did not believe in the salva- 
tion through Christ's blood. Jesus was a historical figure for them and Christ was perceived as a legendary figure of Christian myth (Balogh 1875: 136). The shared core theological doctrines as well as the very fact that Debrecen considered to join the Evangelical Alliance bears testimony to their orientation toward Scottish evangelical theology.

Although liberal theology still held a grasp on some of the intellectual mind of the Reformed Church in Hungary after the mid-1870s, it was the Scottish Reformed theological impact coupled with German intermediating theology (Vermittungstheologie in German) that began to fertilise the soil of Hungarian Reformed spirituality to a degree that was perhaps last seen in the 1600s due to Puritanism. It could be stated that Reformed evangelicalism conveyed through a Scottish Reformed tradition, which also integrated continental Pietism because the leaders of the Scottish mission station were Dutch or German Pietist for decades. This impact permeated Hungarian Reformed piety decisively from 1860 s till 1910 s. It produced not only a new form of praxis pietatis, practice of piety and spirituality but it also proved to be-perhaps we can say without exaggeration-the most influential theological trend in the twentieth century. The small seed, which Scottish planted in 1841, bore its fruits in the long run chiefly owing to the bursary programme at New College, Edinburg which began in 1865. Ferenc Balogh's role was crucial to convince the Scots that there would be an interest from Hungarian Reformed centres of learning who would send students to study at New College. Throughout the next seven decades advanced not only into Hungarian Reformed theology but also into its ecclesiastical structures to which we shall turn our attention. First voluntary organisations were set up copying the Scottish evangelical sample that found its way to the very structure of the national church. To allude forward to the pinnacle of the fascinating development it is worth mentioned a remarkable fact that by 1933 the national synod of Reformed Church of Hungary introduced a mission law, (Gonda 2008: 46) thereby officially incorporated the revivalist, mission minded stance expressed by new orthodoxy of Debrecen and the emerging Reformed evangelical and Pietist movements embodying themselves in voluntary societies within the Reformed Church.

\section{A Theological Impact through Books, Tracts, Establishment of Societies (YMCA, Sunday School, Women's Guild) and Periodicals}

To offer a short overview of the means by which popular Scottish Reformed theology was spread one needs pay attention to the following fact: the Edinburgh scholarship fund proved to be the main channel (Hörcsik 1988: 161-182). Students who studied there often became evangelicals, or sympathetic to the movement. In three areas we may see their impact. First, in the ecclesiastical structures they exerted influence since many of them rose to 
prominent positions in the church. They became church leaders like deans or even bishops, or secured jobs as professors at theological universities and colleges of Debrecen, Budapest, Pápa and to some extent Sárospatak and Kolozsvár. Secondly, the bursars occupied key positions in the newly established voluntary and home societies that became increasingly influential in the life of the church. Finally, all of these persons impacted Hungarian Reformed piety through translating evangelical theological books, tracts and songs. They also published articles about conversion, Biblicism and Christocentric life in newly established periodicals and wrote devotional books for the general publics and textbooks for students training for ministry.

At Debrecen Reformed College, Ferenc Balogh and his former student Lajos Csiky, professor of Practical Theology maintained close contacts with the Scottish theologians, church leaders and missionaries in Budapest. In 1869 Balogh modelled a Theological Self-Training Society (Hittanszaki Önképzőköri Társulat) on the Edinburgh missionary society for students which he saw in the spring of 1865 (Szombathy 1969). This society influenced generations of students who became 'evangelical' ministers, professors or layman of the Reformed Church carrying on the spirit of New Orthodoxy of Debrecen. Balogh became the first president of MEKDSz (Fellowship of Evangelical Students of Hungary) in Hungary in 1904 and had an impact on Gábor Kónya, the first travelling secretary of the YMCA (Forgács 1905: 295-296). He wrote many articles on the importance of Bible and supported the distribution of Bibles which proved to be a useful way of conveying the gospel. His Edinburgh diary which he wrote every single day during his stay in Edinburgh, witnesses how he admired the devotion of British Christians to the distribution of the Bible. For this end, he worked closely with the British and Foreign Bible Society for many years (Balogh 1864: 56). As recognition of Balogh's cooperation with the Bible Society, he was elected an honorary member of the society in 1904 (Ötvös 1997: 141). Lajos Csiky, who was also a bursar in Edinburgh, held a great sway on theological students in Debrecen. Having become a fellow professor to Balogh, Csiky produced many articles on mission and also translated Scottish and English evangelical literature. He also encouraged the bursars of Edinburgh to do likewise (Zoványi 1977: 128). For example, Antal Vargha, a bursar of 1908 translated a tract into Hungarian entitled 'Naámán megtisztulása' (The Purification of Naaman). The bursars also produced articles about the life of the Scottish Church and naturally formed a circle of like-minded evangelicals.

In Budapest, the first dominant figure was Aladár Szabó. Just before the resettlement of Scottish Mission to Pest in 1857 liberal theology became the dominant power in the elite of Protestant circles of Budapest, which partially accounts for the unsuccessful endeavours of the Scottish Mission station 
in Pest. Professor Mór Ballagi preferred German liberal theology to Scottish evangelicalism. However Szabó, who also became a bursar in Edinburgh, as a young student was instrumental in founding societies like YMCA and started Sunday schools for children in the 1880s. Together with many of his friends he began to plant new churches in Budapest and with the aid of the Scottish missionaries he launched evangelisations, supported the foundation of women's societies for the spread of the gospel. This had not escaped the eyes of the new ecclesiastical leadership who perceived his effort favourable and appointed him as a professor in 1888. By 1880s the most powerful figure of liberal theology, Mór Ballagi retired. He, as well as other liberal professors, was replaced by some moderate teachers at Reformed Theological Seminary in Budapest. Thus, there was a gradual shift from the liberal stance of the Ballagi era to a more confessional one represented by new professors such as Farkas Szőts and Elek Petri. Béla Kenessey's and Szabó's appointment ushered in the next new era of a more decided tone of revivalism. This trend grew stronger as several Edinburgh bursars were appointed to professorship between 1903 and 1914. Amongst the bursars from Budapest Szabó was the most prominent. Seventeen years at the Budapest Theological Seminary enabled him to influence an entire generation of students, including such characters as István Csürös, who became the leader of the YMCA of the Reformed Church, Richard Biberauer, Gyula Forgács and other key figures in the newly established home mission organisations. Almost all the home mission societies, which made a lasting impact on Hungarian Reformed Christian thought and practice, were initiated by former Edinburgh bursars. In 1905, Szabó was elected to become one of the ministers of the prominent Kálvin tér church. There he established the most effective evangelical-pietist home mission society named Bethany Christian Endeavour. Through this association, he kept in close touch with leaders of other home mission organisations (Bodonhelyi 1955: 98). István Pap Bilkei, another bursar, became a professor of practical theology and canon law in Budapest in 1905 succeeding the liberal Albert Kovács. He received his first evangelical impetus from Szabó and the Scottish Mission while taking part in the establishment of the Sunday school movement in 1882. In Edinburgh, he came under the influence of J. G. Cunningham, minister of St. Luke's church and John Kerr whose 'Lectures on the History of Preaching' proved to be a useful teaching tool for him (Csekey 1943: 7). Throughout his thirty-year professorship, Bilkei clearly stood for home mission and promoted evangelical revival. To achieve this, he drew on Scottish theology. One of his students, Sándor Csekey_who later became professor himselfremarked that he 'instilled the love for home mission in the students' (Csekey 1943: 7). 
In Pápa Reformed Theological College, the third place where Scottish evangelicalism made an impact Lajos Csizmadia (1858-1928), translated a number of evangelical books such as Henry Drummond's 'Natural Law in the Spiritual Life' and John Kerr's book mentioned earlier through which he imparted Scottish evangelicalism (Zoványi 1977:129). He was one of the earliest bursars (1883/4) and became professor of practical theology in 1901 (Hörcsik 1988: 22). Csizmadia was a member of the Bethany CE, and due to his strong ties with the Mission his young student József Pongrácz was put into contact with the missionaries. It is fascinating to see how the networking of revivalists functioned in the case of József Pongrácz a professor of New Testament. Before becoming a bursar of Edinburgh, he was already involved in the life of home mission representing Pápa in 1904 at the foundation of MEKDSz (Szabó 1941: 44). Pongrácz stayed for two years in Edinburgh from where he travelled to the WSCF (World Student Christian Federation) conference in Liverpool. Upon his return to Hungary he became secretary to the bishop of the Transdanubian Church Province, just like István Hamar in Pest and soon secured a professorship at Pápa Theological Seminary in 1910 (Zoványi 1977: 482). He was an expert on New Testament and emphasised the importance of reading the Bible daily just like Szabó (Pongrácz 1908: 2). Pongrácz regarded home mission organisations which were directly or indirectly all the fruits of Scottish evangelicals like Bethany C. E. and MEKDSz as a means of leading others to Christ (Pongrácz 1910, 2 October). He prompted his students to become involved in Sunday school work as well as prayer meetings for foreign mission. László Pataky, one of his students, mentioned in his memoirs how seriously Pongrácz took prayer life (Pataky 1988: 45-56). He, like Csizmadia, Bilkei, and Csiky was very productive in translating books from English into Hungarian. His correspondence with the retired Andrew Moody in Hungarian resulted in the publication of Jézus és Zákeus (originally Sought and Saved) (Pongrácz 1909: 16 April), Az üdvösség napja (The Day of Salvation) (Pongrácz 1909: 7 May), and Diadalom (Triumph) to mention just a few (Pongrácz 1909: 16 February). Finally, we must allude to the fact that the aftermath of World War II. forced the Reformed Churches to reorganise themselves under the new states emerging as an outcome of Treaty of Trianon. From Upper Hungary, which was occupied by Czech and Slovak forces and the Czechoslovakia was created, the minority Hungarians needed to start organising their own entirely new structures especially theological education. Béla Sörös, a former Edinburgh scholar established a Training College in Losonc and adapted the Scottish model of education. It meant that students were assigned to a minister who was outstanding in one of the theological disciplines and studied and work with him for a year or so (Somogyi 2014: 107). 


\section{The Impact of Scottish Evangelical Theology on the Personal Piety of the Reformed Hungarian}

Here it is our concern to evaluate carefully the impact Scottish Reformed theology and piety made on the Reformed Churches of Hungary. It is what I label 'popular theology' where in the sway of Scottish evangelicalism made its presence felt mostly. Free Church of Scotland theologians and missionaries were imbued by evangelical spirit which maintained the old, traditional confessions and articulations of faith. Through this the newly arrived evangelical theology could connect to confession orientated mind-set of traditionalist theologians of Hungary as we referred to it when discussing the emergence of New Orthodoxy movement in Debrecen. This connection worked well in spite of the fact that the personal piety of the first figures such as Ferenc Balogh, or Imre Révész senirons was different in form and shape from Anglo-Saxon ones. Through this bridge that was provided by a shared theological conviction and view, as well as the means of influence such as devotional and theological books containing traditional theology, bursary programme, evangelisations and establishment of British originated Christian societies a like YMCA, Sunday school and medical outreach the evangelicalism took root in Hungarian Reformed piety to a varying degree. However, the question arises what were major features of this that were transplanted into Hungarian Reformed faith. David Bebbington identified four main qualities which could be useful in defining evangelical characteristics in Hungary: biblicism, crucicentrism, conversionism and voluntarianism. I make use of these categories but intend to reshape and extend them to describe the nature of the new Hungarian Reformed piety, evangelicalpietism brought about by Scottish evangelical Reformed faith.

\section{Biblicism of Evangelical Piety}

Biblicism was successfully transplanted into Reformed piety since Hungarian Calvinist always had a special regard and reverence for the Bible due to its spiritual message, and its importance for preserving national language. Owing to the affirmative stance of New Orthodoxy of Debrecen the authority and divine inspiration of the Bible was well guarded based on the Apostles Creed. Hungarian Reformed revivalist influenced by evangelicalism proclaimed that the Holy Scripture contains all essential spiritual truth which is to be found in its pages. The reverence for the Bible was not just a belief but it was visible through the actions of the converts. Former students of New College, Edinburgh eagerly supported the work of the British and Foreign Bible Society and began to announce the necessity to read the Bible daily for personal spiritual end. For them the Scripture was not just a textbook for theological study but the living word of God. In addition to this, a culture began to appear that believers took their Bibles to church not just 
their hymnbooks or psalter books as it was customary in traditional Reformed piety. By the turn of the twentieth century a hymnbook was edited from English hymns named Hozsánna (1901) which was followed by Hallelujah hymnbook (1944). These were immensely popular among revivalist taking part in all kinds of societies and were in use parallel to the official hymnbook. Later many hymns made their way into the official songbooks of the Reformed Church. It is a remarkable fact that many modern AngloSaxon hymns were brought into the sphere of the Reformed congregations, which were in tone, text and melody very different from the ancient French, already accommodated Geneva Psalms which become 'Hungarian' and from the naturally home-grown songs of personal piety. In general, Hungarian songs mirrored the sorrowful experience of Hungarian Protestant faith whereas the British ones were more joyful and triumphant which may also be due to the national and successful political advancement of Great Britain and the USA. Through the Scots, a totally new phenomenon began to emerge. The powerful, rhythmical, ear-catching melodies of Sankey and Moody's revivalist songs took root in the revivalist circles swayed by Scottish piety. Hymns like 'How sweet this good news to us' (Mily drága nékünk ez a jó hir?) written by Fanny Crosby underlined the significance of the Gospel, and another song entitled 'The Opened Holy Bible', $(A$ megnyitott szent Biblia) attest how dear the Bible was held by revivalist. Not only the establishment in Bible and Tract societies shows how much the Bible was treasured but also the revivalist songs bear witness to it. [It can be found in the revivalist and very popular Hallelujah, hymn number 138.]

\section{Christ and Crucicentrism. Ancient Christology Upheld}

The second feature of Scottish evangelicalism was its firm christological stance, its acceptance of the core belief about the divinity, incarnation and resurrection of Christ as it was articulated in the Creed (Bebbington 2004: 133-150). Evangelical theologians like William Cunningham, Thomas Chalmers and Robert Rainy (Cheyne 1983: 60-87) all subscribed to the Evangelical statement of faith which declared 'The Unity of the Godhead, and the Trinity of the persons therein, the incarnation of the Son of God, his work of atonement for the sins of mankind, and his mediatory intercession and reign' (McGrath-Marck 2004: 428). Similarly, the Debrecen Confession of faith clearly repeated this conviction adding to it the old age recognition of Reformation that 'the justification of the sinner is possible by faith alone' (Kovács 2010: 198). Lajos Kálmán, an orthodox theologian rejected the liberal stance of modern theology which denied the corruptness of human being naively thinking that it is innately good, a non-Christian teaching (Kálmán 1875: 293-284). Ferenc Balogh pointed out in his debate with the liberals that salvation through Christ and justification are essential 
beliefs for the Christian faith (Balogh 1875: 135). Mihály Tóth, professor of Practical Theology in Debrecen articulated neatly that the divine redeemer is knocking on the door of the heart of human beings, and gives an answer to all concerns of the believers. He argued that through faith in Christ we shall be perceived just and spotless before God. However, God is able to work in us only if our hearts accept and acknowledge the testimony of the Scriptures (T. M. 1875: 64). The life of a born-again person will become virtuous life because he or she is justified in Christ. Such life seeks to follow and become like Christ following the words of the Holy Scriptures. Tóth supported his statement by biblical verses: 'since you have been born again, not of perishable seed but of imperishable, through the living and abiding word of God' (1 Peter 1:23), therefore 'You shall be holy, for I am holy' (1 Peter 1:16) and he encouraged the newly converted Christians to follow Jesus's step: 'You therefore must be perfect, as your heavenly Father is perfect' (Matthew 5:48). Here the emphasis is on the death of Christ's on the cross by saving the sinful man and is also on his grace which justifies us. It is a false calculation of liberal theology which takes man sinful nature easily and light-heartedly. Tóth argued that it is also a wrong to think as imaged by liberals that as science and culture advances sin gradually declines and eventually disappears, since it is not merely the result of fallible finite nature of human beings. The confessional theology of Debrecen firmly refused the pseudo theology of liberals offering a 'flattering self-salvation'. Moreover, it went further by claiming that all are anti-Christians, who deny Christ's salvific work, even if they openly do not say it. It threw light on the fact if someone denied the universality of sin that consequently led to the nonacceptance of Christ's salvation and 'it would also result in the denial of the historical facts of revelation' (T.M. 1875: 63). Finally, Sámuel Tóth a systematic theologian from Debrecen assigned what the main aim of a confessing Christian life for theological professors was: 'Our main vocation and responsibility is to lead the people, whose shepherd we are, to our sweet Redeemer. The Saviour-I believe_cannot be anybody else (neither in Budapest and Sárospatak theological seminaries) but Jesus Christ who was crucified and resurrected on the third day' (Tóth 1882: 153).

Clearly enough, theologians of the New Orthodoxy of Debrecen, just like Scottish evangelicals, affirmed that the 'the work of the Holy Spirit in the conversion and sanctification of the sinner' is an essential tenet of faith for the Christian believers. It is true that Mihály Tóth or Sámuel Tóth who studied in Germany were not influenced directly by Scottish Reformed faith, however, their traditional and orthodox stance was welcomed by Scottish evangelicals who knew about their publications through Ferenc Balogh. Thus, it has been demonstrated that a strong crucicentrism was dear in both Reformed traditions: the Hungarian Neo Orthodoxy and the Scottish 
evangelicalism of the Free Kirk. With this observation, we arrive at the third feature.

\section{A Salvation-Centred Preaching}

The phenomena of conversionism started with the evangelisations of A. N. Sommerville, a Scottish evangelist of the United Presbyterian Church. It is claimed so as evangelising sermons appeared for the first time on a large scale in the Reformed congregations in Hungary during Sommerville's preaching campaign/crusade. He travelled across Hungary during the winter of 1887/88 escorted and hosted by former Edinburgh students who became professors like Balogh, Csiky and Szabó or ministers like József Szalay and Ferenc Kecskeméthy (both former bursars) working in large or small congregations in the countryside. Sommerville was the first person to preach a sermon for calling people to forward in the church to convert. The genre of preaching was to be named as evangelisation (evangélizáció in Hungarian), a form of preaching which was completely unknown to Hungarian Reformed piety in the nineteenth century. He also introduced Anglo-Saxon hymns of Ira Sankey and Moody using a portable organ and called for the conversion of heart which masses of lay people listened to (Révész 1943: 1045). One of the songs was 'I know my Redeemer lives and has prepared a place' (Tudom az én megválóm él) that is still extremely popular in the official Hymnbook of the Reformed Church of Hungary. The ear-catching and melodic songs attracted the attention of people in which the texts talked about the need of conversion through Jesus's redeeming act. One of first evangelical revivals was among the peasants of Hungary as the population of Hungary mostly consisted of agricultural workers (Szalay 1893: 75). The need for a conversion of heart, a repentance of sin and a visible change of Christian life as norms for 'converted' Christians began to appear on the scene of Reformed piety due to Scottish evangelical and German pietist impact (Kovács 2006: 262). [Hymn nr. 421 is in the official Hymnbook of the Reformed Church of Hungary. About its reception into Hungarian hymnody see László Draskóczy’s writing. http://egyhazzene.reformatus.hu/v/313/ downloaded 18 August, 2018.]

Evangelical hymns praising and glorifying Jesus, like 'What a friend we have in Jesus'(Ó mily hü barátunk Jézus, Hallelujah, 162), (Bailey 1950: 405406), 'The Church's one foundation Is Jesus Christ her Lord' (Az egyháznak a Jézus a fundamentuma) written by Samuel John Stone, 'The Great Physician now is near, the sympathising Jesus' (Az áldott orvos közeleg,) or the song 'Love Divine, all loves excelling' (Hittem benned most ime Zengem) written by Charles Wesley all introduced terminologies, concepts like Jesus is a 'friend, 'captain', physician' and other popular religious expressions which were not typical expressions of personal piety in Hungarian Reformed faith at all. 
Converts often used this new evangelical 'language' when they made a confession, or gave a public testimony. [The hymn was written by the Anglican priest Stone, and set to tune by the grandson of Charles Wesley, Samuel Sebastian Wesley. It can be found in Hallelujah hymnbook, number 15.]

Although doctrinally the Scottish and Hungarian Reformed traditions adhered to the same tenets, and their respective symbolic books rested on Calvin's teaching yet the consequent development of various trends of Calvinism were different. The constant self-flagellating language of evangelical preachers about sin in sermons was unusual in Hungarian piety since most of the preachers of nineteenth century Hungary interpreted the Bible as a social and moral guide for life but not as a book proclaiming the gospel that calls for repentance and turn to Christ (Kovács 2010: 155). This 'negligence' is due to the fact that it was assumed that church folk was already Christian and why to call for conversion. In this regard, Hungarian Reformed faith was closer to the moderate stance of the Church of Scotland and almost completely lacking such a phenomenon what Evangelicalism embodied in Scotland. But it began to change from 1865 onwards. Scottish evangelicalism, as presented by the former students, Scottish missionaries laid a heavy emphasis on the acknowledgement of sin, a personal conversion even of baptised Christians. Therefore, Scottish evangelical theology and praxis was responsible for introducing a new kind of spirituality into Hungarian Reformed Christianity. By doing so it also contributed to the creation of ecclesiola, that is a congregation/community of 'believers' within a local church who stood in sharp contrast with those of adhering to the valued religious tradition Calvinist faith (Gonda 2008: 39; 45). This created tensions in congregations. The newly shaping evangelical-pietist group favoured besides the traditional hymnbook the 'modern', Anglo-Saxon revivalist or Pietist songs like 'Would you love to be free from you sin?' (Vágyol-e elhagyni büneidet?) or 'Oppressed with sin and woe' (Bár bün és kín gyötör) which was written by Anne Bronte and the lyric composed by S. Howard. Both songs were translated by Aladár Szabó, the father of Hungarian home mission. Another song entitled 'Unto the Lamb of God I lay my sin' (Az Isten bárányára) written by Bonar Horatius. Similar debates between liberals, traditionalist and born again evangelical-pietist began to surface in congregations but a lot of people realised the need to bring in a fresh, lively and devout Christian life into the Reformed piety. This led to activities to proclaim the gospel, give testimonies and carry out charitable work in the name of Jesus. [It can be found in Hallelujah hymnbook, number 209. It can be found in Hallelujah hymns book number 21. It was translated by Mrs Gyula Vargha and Tamás Vargha. According to http://hu.scribd.com/doc/25046214/450-Draga-Dolog-Az-UrIstent-Dicserni, the tune of the hymn is attributed to Krisztina Roy (18611937). It is number 459 in the official hymnbook of the Reformed Church 
of Hungary. Bonar was part of the Scottish revivalism which impacted Hungarian evangelicalism and pietism through various means.]

\section{Voluntarianism. The Belief that the Gospel Needs to Be Expressed through Social and Spiritual Action}

Word and action were held tightly together by contemporary evangelicals and Pietist. Preaching about the gospel's liberating message from sin and doing mission, offering spiritual counselling to fellow people as well as executing all kinds of social outreach (mission to orphans, sick, children, women, prostitutes, drunkards) went hand in hand. Action and spreading the Word of God did not exclude but complemented one another. We have already demonstrated how instrumental Scottish evangelicalism was through the former bursars to establish home mission organisations to revive the church. Biblicism, crucicentric Christology and conversionism was supplemented by voluntary actions. Songs played a crucial role in inciting religious fervours along with preaching. There are a number of lively English, Scottish or American evangelical hymns which call for doing something in return for the wondrous gift of love Jesus gave sinners, his life. One of the hymns calls for 'Should I go with empty hand and stand before the Lord?' (Üres kézzel menjek é el?) indicating the urgent need of the believer to offer his or her life us a life of sacrifice for the advancement of the Kingdom of God. Another song 'Hold the fort, for I am coming, Jesus signals still; Wave the answer back to Heaven, By Thy grace we will' (Fel barátim drága Jézus) (Molnár 2014: 62-70) became the most popular song of Evangelicals who started a voluntary movement, the YMCA movement in Hungary (Révész 1943: 29). [It can be found in Hallelujah hymnbook, number 322. It can be found in Hallelujah hymnbook, number 52.]

Through such songs, a new form of piety and religious mentality was introduced which revelled in the heroic act of mission. It defied the work of Satan identified with sins like excessive drinking, stealing, dishonesty, jealousy, bribing, lure to worldly goods or combatted anti-Christian ideologies such as Darwinism, materialism, and the like. The term 'born again' applied to converts recruited from the already baptised Christians' as a theological concept was introduced into Hungarian piety through popular Scottish evangelical theology. The incredible joy from being saved from eternal death had a strong grasp on the soul of the believers who were prompted to evangelise in the streets, arrange special events for giving testimonies and preach in congregations. Many prayer groups were formed which longed to see the church renewed. Thus, a new phenomenon featuring evangelisations, prayer groups, and home mission organisations came into being which all varied in their forms, shape, and content (Kovács 2006: 272-293). These activities were escorted by the itinerary preaching of the colporteurs 
of Bible Society workers employed by Scottish Missionaries (Eibner 1983: 45-54). Many of the workers were Baptist including some Calvinist too. These simply but devout workers, or peasants made a deep impression on people in towns and the countryside. Voluntarianism became a feature of Hungarian Reformed piety through its first group of evangelicals.

\section{Concluding Thoughts}

By the middle of the twentieth century, the Scottish theological impact left its imprint on the piety of Reformed people of Hungary. It has been demonstrated that albeit liberal theology was strong in Hungary and, still there were others who found a common ground in their adherence to traditional doctrines of Christian faith. The Scottish Reformed evangelicalism and the New Orthodoxy of Debrecen both acknowledged the authority of the Bible, kept the Christological assertions found in the Creed. This commonly shared ground enabled them to build further bridges between Scottish and Hungarian Reformed people. One of the main channels was the scholarship programme which paved a way to popular evangelical Reformed theology from Scotland. The theological impact as well as the practices of daily Christian life with its emphasis on Bible, Christ, conversion and social action together with spiritual nourishment became integral part of Hungarian Calvinism to a degree that even a country like Hungary which was isolated since Reformation till the late nineteenth century began to develop a missionary awareness (Kool 1995). It is a remarkable fact that many top church leaders contributed to the renewal of the Reformed Church of Hungary and officially a mission law was passed by the national synod (Gonda 2008: 42). Surely evangelicals became a significant, influential minority which with its organised structures of societies, its presence in national church structures profoundly influenced the course of events in the life of the Reformed Church (Bucsay 1985: 222-224).

\section{Bibliography}

Bailey AE (1950) The Gospel in Hymns, New York: Charles Scribner's Sons.

Balogh F (1864) Londoni Napló (London Diary of Ferenc Balogh) Debrecen: Debreceni Egyetemi Könyvtár Kézirattára. Ms 28/2.

Balogh F (1875) Nyilt válasz Ballagi Mór úr 2. nyílt levelére II (An Open Letter as a response to the 2. Open Letter of Sir Mór Ballagi) EPL 1. 15.

Barcza J (ed) Tovább. Emlékkönyv Makkai László 75. születésének évfordulójára. Debrecen: Debreceni Református Kollégium Nyomdája.

Bebbington DW (2004) Evangelical Theology in the English-speaking World during the Nineteenth Century. Scottish Bulletin of Evangelical Theology 22(2): 133-150. 
Bebbington DW (1996) Scottish Cultural Influences on Evangelicalism. Scottish Bulletin of Evangelical Theology 14(*): 23-36.

Bodonhelyi J (1955) A belmisszió kora (1896-1918), (The Era of Home Mission). A Budapesti Református Theológiai Akadémia története 1855-1955 (The History of the Reformed Theological University in Budapest). Budapest: A Református egyetemes konvent sajtóosztálya.

Brown D (1872) Life of the Late John Duncan, 2nd revised edition. Edinburgh: Edmonston and Douglas.

Bucsay Mihály (1985) 125 Jahre Deutsch-Sprachige Reformierte Gemeinde in Budapest (1859-1984). In Hauptmann P (ed) Kirche im Osten. Studien Zur Osteuropaischen Kirchengeschichte Und Kirchenkunde 28. Goettingen.

Bucsay M (1985) A protestantizmus története Magyarországon 1521-1945 (The History of Protestantism in Hungary 1521-1945). In Auer K, Ádámné Révész G (trans) Budapest: Gondolat.

Chalmers T (1846) On the Evangelical Alliance. Its Design, Its Difficulties, Its Proceedings, and Its Prospects, with Practical Suggestions. Edinburgh.

Cheyne AC (1983) The Transformation of the Kirk. Victorian Scotland's Religious Revolution. Edinburgh: The Saint Andrews Press.

Coffey J (2003) Puritanism, Evangelicalism, and the Evangelical Protestant Tradition http://www.reclaimingthemind.org/papers/ets/2003/Coffey/Coffey.pdf (downloaded 2014.03.23).

Csekey S (1943) Bilkei Pap István, Budapesti Református Theologiai Könyvtár, 4. 2. Mezőtúr: Corvina Nyomda.

Drummond H (1895) A természeti törvény a szellemi világban (Natural Law in the Spiritual World). Budapest: Hornyánszky Viktor.

Duncan J (1842) Extract Letter from Rev. Dr. Duncan to Rev. Dr. Candlish Pesth, January 24, 1842. Home and Foreign Missionary Record of the Church of Scotland 2(4): 45-46.

Eibner JV (1983) British Evangelicals and Hungary 1800-1852. The Journal of the United Reformed Church History Society 3(2): 45-54.

Forgács Gy (1905) Titkári jelentés (A Report of the Secretary). Protestáns Egyházi és Iskolai Lap (PEIL), 48.19.

Gaál S (2004) Két kálvinista centrum egymásra találása: a skóciai ösztöndíj létrehozása (The Meeting of two Centres of Calvinism and the Establishment of the Bursary in Scotland). En Christo. Tanulmányok a 85 éves Dr. Bütösi János tiszteletére szerk. Debrecen: Fábián Nyomda.

Gonda L (2008) The Service of Evangelism, The Evangelism of Service. Utrecht: Utrecht University Press.

Hörcsik R (1988) Az edinburghi magyar peregrináció rövid története (A Short History of Hungarian Peregrination to Edinburgh).

Isbell S (1993) Duncan, John. Camerun, N. M. de S. (ed) Dictionary of Scottish Church History and Theology. Edinburgh: T. \& T. Clark. 
Kálman L (1875) Észrevételek Kisantal Sámuel hitvallására II (Remarks regarding the creed of Sámuel Kisantal) EPL 1.4.

Keith A (1833) Evidence of the Truth of the Christian Religion from the Literal Fulfilment of Prophecy; Particularly as Illustrated by the History of the Jews and by the Discoveries of Recent Travellers. Edinburgh: Waugh and Innes.

Kerr J (1905) Egyházi beszédek. Pápa: Főiskolai Nyomda.

Kool AM (1995) Az Úr csodásan müködik, 3 volumes. Budapest: HarmatPMTI.

Kovács Á (2004) A Budapesti Ev. Ref. Németajkú Leányegyház eredete és története 1858-1869 (The History of the German-speaking Reformed Affiliated Church of Budapest 1858-1869). D. Dr. Harsányi András Alapítvány Kiadványai 10, Debrecen: Fábián Nyomda.

Kovács Á (2010) Hitvédelem és egyháziasság. A debreceni újortodoxia vitája a liberális teológiával (Apologetics and Adherence to the Church. The Debate between the New Orthodoxy of Debrecen and Liberal Theology). Budapest: L'Harmattan.

Kovács Á (2006) The History of Free Church of Scotland's Mission to the Jews and its Impact on the Reformed Church of Hungary 1841-1914. Frankfurt am Main: Peter Lang.

Kovács Á (2001) The Origin of the Scottish-Hungarian Church Relations: The Settlement and the First Years of the Scottish Mission in the 1840s. 4, Debrecen: Debreceni Református Kollégium Nyomdája.

Kövy Zs (ed) A Pápai Református Gyüjtemény évkönyve (The Yearbook of Collections of Pápa Reformed College). Pápa: A Dunántúli Református Egyházkerület Nagykönyvtára.

McGrath A, Mark DC (2004) The Blackwell Companion to Protestantism. Oxford: Blackwell.

Molnár SK (2014) A Fel barátim drága Jézus kezdetű ének története Magyarországon (The History of the Song 'Hold the fort; Under the Banner of Jesus' Hungary). Egyháztörténeti Szemle 15(3): 62-70.

Moody-Stuart A (1872) Hungarian and Bohemian Bursaries. Free Church of Scotland Missionary Records 10(118): 93-95.

Ötvös L (1997) Balogh Ferenc életmüve (1836-1913) (The Life and Work of Ferenc Balogh). Debrecen: Karcagi Nyomda.

Pápai Református Gyűjtemény (Pongrácz József Collection in Pápa Reformed College) DREL 22. d., Letter of József Pongrácz date 2 October, 1910.

Pápai Református Gyűjtemény (Pongrácz József Collection in Pápa Reformed College), DREL 22. d., Pápai Református Gyűjtemény (Pongrácz József Collection in Pápa Reformed College). Letter of József Pongrácz date 2 October, 1910. 
Pápai Református Gyűjtemény (Pongrácz József Collection in Pápa Reformed College) DREL 22. d. Letter from Andrew Moody to Pongrácz 16 April 1909.

Pápai Református Gyűjtemény (Pongrácz József Collection in Pápa Reformed College) DREL 22. d. Letter from Andrew Moody to Pongrácz 7 May 1909.

PRGy, Pongrácz József Collection, DREL 22. d. Letter from Andrew Moody to Pongrácz 16 February 1909.

Pataky L (1988) Az imádkozó Pongrácz József. Pongrácz József emlékülés Pápán (An Anniversary of József Pongrácz. The Praying man: József Pongrácz), 1985 november 15.

Pongrácz J (1908) Bibliaolvasás (Studying the Bible), (n. p.) Klny.

Randall I (2001) One body in Christ: the History and Significance of the Evangelical Alliance. Carlisle: Paternoster.

Révész I (1943) Egy fejezet a magyar református ébredés történetéből (A Chapter from the History of Hungarian Reformed Awakenings). Theológiai Szemle 19.

Rooy SH (1965) The Theology of Mission in Puritan Tradition. Grand Rapids: MI.

Somogyi A (2014) Losonci Teológiai Akadémia tudományművelése (The Education at Theological Academy in Losonc) Teológiai Fórum 8(1): 92124.

Scult M (1978) Millennial Expectations and Jewish Liberties. Neuser J (ed) Studies in Judaism in Modern Times 2. Leiden: Brill.

Sheldon CM (1903) Az ő nyomdokain (In His Footsteps). Budapest: Magyar Protestáns Irodalmi Lap.

Szalay J (1893) Sankey énekeiből. Ne félj csak higyj (From Sankey’s Hymns. Do not Worry but Have Faith). Keresztyén 2(10): 75.

Szalay J (1893) Sankey énekeiből. Ó Boldog Nap. (From the Songs of Sankey. What a Happy Day) Keresztyén 2(9): 67.

Szombathy Gy (1975/1969) A teológus ifjúság (Youth in the Theological Academy). Budapest: SNTM: Bűnösség és váltság (Sin and Atonement). EPL 1(7): 63-64.

Tóth S (1882) Húsvéti igazság kerdéséhez (About the Truth of Easter). Debreceni Protestáns Lap 2(16).

Walls AF (1993) Missions. Camerun, N. M. de S. (ed) Dictionary of Scottish Church History and Theology. Edinburgh: T. \& T. Clark.

White G (1977) 'Highly Preposterous': Origins of Scottish Missions. Records Scottish Church History Society 19. Edinburgh.

Zoványi J (1977) Magyarországi protestáns egyháztörténeti lexikon (Protestant Lexicon for Hungarian Church History). Ladányi S (ed) third enlarged 
edition. Budapest: A Magyarországi Református Egyház Zsinati Irodájának Sajtóosztálya. 